\title{
Student Self-Development through Cooperative Problem Based Learning (CPBL)
}

\author{
Nor Hidayah Abd Radzaz, Nina Diana Nawi, Fatin Aliah Phang, Aerma Nurazalina Musa
}

\begin{abstract}
Cooperative Problem Based Learning (CPBL) is a highly student-centred approach of learning specifically suited to cater the millennial students. In this study, CPBL was conducted at 12 selected class in Johor secondary schools for the students at the age of 14 years old. Low Carbon Society (LCS) was used as the core theme by integrating STEM subjects where the students were exposed to technology, teamwork, peer-to-peer learning, presentation and critical thinking processes. Three phases of CPBL were executed to shift the teachers and students from highly teacher-centred paradigm to student-centred paradigm. The reflections of the students were collected to analyse the development of the students on their cognitive, psychological and self-development. During the first phase, the students encountered the trauma cycle before they moved to the next phase that developed their cognitive, psychological and self-development. It was found that upon entering the third phase of CPBL, the students have improved self development and skills specifically on interpersonal skills, self-esteem, skills development. The study revealed that through the designated environment learning process of $C P B L$, the students involved actively in grasping the low carbon concepts. Most importantly, the external motivation and pressure given enabled them to embrace the concept and awareness which ultimately gave significant impact for the student's self development and skills.
\end{abstract}

Keywords: Cooperative Learning, Problem Based-Learning, Self-Development.

\section{INTRODUCTION}

Cooperative Problem-Based Learning (CPBL) has been gaining interest among educators [1] because previous studies show the ability of CPBL approach in developing students' characteristics that leads to self-development. For instance, CPBL is able to develop $21^{\text {st }}$ century skills needed by students to obtain future jobs such as problem solving skills, critical thinking and creativity [2-4]. However, this learning approach is opposite to the conventional teacher-centred learning approach where students highly depend on the teacher [5]. CPBL requires the learning process to be designed in the student-centred manner by integrating two learning methods which are Cooperative Learning (CL) and Problem-Based Learning (PBL) [1-2]. Highly student-centred approach requires students to take the initiative to make notes and information, involve in

Revised Manuscript Received on September 22, 2019.

Nor Hidayah Abd Radzaz, Faculty of Social Sciences and Humanities, Universiti Teknologi Malaysia, Johor, Malaysia.

Nina Diana Nawi, School of Education, Faculty of Social Sciences and Humanities, Universiti Teknologi Malaysia, Johor, Malaysia.

*Fatin Aliah Phang, Centre for Engineering Education, Universiti Teknologi Malaysia, Johor, Malaysia.p-fatin@utm.my

Aerma Nurazalina Musa, Johor State Education Department, Johor, Malaysia. peer-to-peer learning, understand the issues and decide what to learn and how to learn [2]. According to Phang et al. [2], CPBL is able to develop student's knowledge, awareness, thinking skills and attitude specifically on learning, team working, stress management, aspire to make the world a better place to live. Thus through CPBL approach, students are can achieve self-development.

Problem-based Learning (PBL) provides students with guided experience in learning through solving complex, real-world problems. PBL was designed with several important goals [6-7] to help students to:

1) construct an extensive and flexible knowledge base;

2) develop effective problem-solving skills;

3) develop self-directed, lifelong learning skills;

4) become effective collaborators; and

5) become intrinsically motivated to learn.

In one cycle of CPBL, there are three phases which are, Phase 1: problem restatement, problem identification. Phase 2: peer teaching, synthesis of information, and solution formulation, and Phase 3: generalization, closure and reflection. For every cycle, students are required to provide problem restatement and problem identification, where they learn to identify and find their learning issues. The learning process requires team working. A good team work consists of five principles of cooperative learning that must be emphasized and promoted throughout the CPBL cycle [10]. The five principles are positive interdependence, individual accountability, face to face interaction, appropriate interpersonal skills and regular group function assessment.

\section{CPBL CLASSES}

Phase 1: Problem restatement and problem identification

At the beginning of phase 1, teachers introduce the CPBL framework, CPBL cycles and the workload required for CPBL process to the students. In the early weeks of phase 1, teachers familiarize the students with the CPBL approach. The students are given materials such as the CPBL cycle and a sample problem. Teachers give a problem to the students and the students discuss in their team to understand the problem. From the discussion, the students need to make problem restatement (PR) and problem identification (PI) in their team, and later whole class discussion [11].

\section{Phase 2: Peer teaching, synthesis of information, and} solution formulation

In phase 2, the students conduct peer teaching among themselves to explain what they have learnt. The students may conduct some activities to further synthesize or apply the

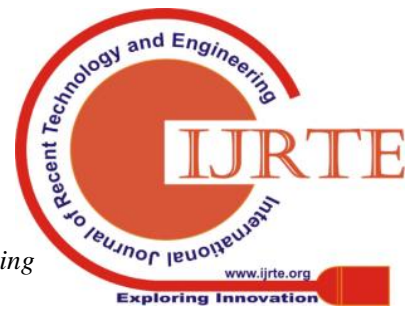


newly learnt knowledge. For example, they can conduct research through observation, survey or interview. With better understand among the students they can come to a solution. Each team is responsible to submit a report on their method, findings and discussion.

\section{Phase 3: Generalization, closure}

For the final phase, the students make presentation, reflection, team rating and feedback on each team. From this activity, each team compare the solution between them and get a feedback form other teams. Form the comments and suggestions by others, the students are able to make improvement to their solution and understanding of the topics.

\section{RESEARCH METHOD}

The CPBL classes were conducted at 12 secondary schools among form two students (aged 14 years old) in Johor, Malaysia. The CPBL classes were held for one to two hours every fortnight from March to October 2018. In the CPBL class, Low Carbon Society (LCS) had been used as the theme by integrating Science, Technology, Engineering \& Mathematics (STEM) subjects. Four teachers of different subjects conducted the classes. They team teach as facilitators. Before the classes, they were trained on Active Learning, Cooperative Learning and Problem-Based Learning. They also underwent workshops to design the problems based on LCS theme and their lesson plans.

A qualitative research design was conducted to investigate the students' self-development from each phase of CPBL classes. The progress was reported from students' reflection that they wrote after completing each phase. The students were asked to reflect and write about what they have learnt and feel at the end of every phase [2]. The acquired data was analysed using thematic analysis [12] to identify the skills and self-development that students gained through CPBL class. A total of 78 students submitted their reflections for each phase.

\section{RESULT AND DISCUSSION}

\section{A. Student Development in Cycle 1: The Traumatic Cycle}

In cycle 1 , the students show high degree of dissatisfaction which is expected in this study. The condition in cycle 1 is also known as the 'trauma cycle' that stipulates the students to feel shocked, emotional, denial and resistance [2]. Table 1 shows the experience of the students which is categorized into three areas, namely cognitive, psychological and self-development. In the cognitive area, the students experienced unclear about the CPBL programme.

The traumatic experienced in cycle 1 had been predicted based on previous study [2]. According to Phang et al. [2], there were several reasons that leads to traumatic event among students:

1. The cycle of CPBL as the principle and method were not well explained

2. CPBL activities required longer time engagement
3. The unpredicted work load makes students anxious and feeling like giving up

4. The application of new learning environment was inconvenience, unfamiliar and unsecure.

5. The individualistic attitude from certain group members made low participation and involvement in CPBL group activities.

Table- I: The description on the development area during traumatic cycle of CPBL cycle 1 .

\begin{tabular}{|c|c|c|}
\hline $\begin{array}{l}\text { Development } \\
\text { Area }\end{array}$ & Coding & Description \\
\hline \multirow[t]{3}{*}{ Cognitive } & Unclear & $\begin{array}{l}\text { Students did not fully understand the CPBL } \\
\text { process and the purpose using CPBL } \\
\text { approach. They need to find information but } \\
\text { at one point they really did not understand on } \\
\text { what they need to do and the content of the } \\
\text { information itself. }\end{array}$ \\
\hline & Expectation & $\begin{array}{l}\text { Even though the students faced difficulties in } \\
\text { the CPBL class, somehow in a positive way } \\
\text { they were aware that the CPBL class can } \\
\text { help them to improve themselves in the } \\
\text { future. }\end{array}$ \\
\hline & Knowledge & $\begin{array}{l}\text { The problems that used in the CPBL class } \\
\text { are related to low carbon society which are } \\
\text { new to the students. From the CPBL class, } \\
\text { the students gained more knowledge about } \\
\text { low carbon society from the class activities } \\
\text { and while finding the information } \\
\text { themselves. }\end{array}$ \\
\hline \multirow[t]{3}{*}{ Psychological } & Stress & $\begin{array}{l}\text { The students felt stressed as the learning } \\
\text { process was different from the traditional } \\
\text { way. They needed to find the information } \\
\text { themselves and faced with difficulties to } \\
\text { understand the information because it was in } \\
\text { English. They also needed to struggle with } \\
\text { tasks from the CPBL class and homework } \\
\text { from other subjects while the time was very } \\
\text { limited. }\end{array}$ \\
\hline & Bored & $\begin{array}{l}\text { In cycle } 1, \text { most of the CBPL activities were } \\
\text { performed in class. The activities also } \\
\text { required reading, discussion and } \\
\text { presentation in class which made the } \\
\text { students felt bored in the CPBL class. }\end{array}$ \\
\hline & Self-esteem & $\begin{array}{l}\text { In the CPBL class, the students have to be } \\
\text { active in discussion and presentation. As the } \\
\text { students rarely talk in front and } \\
\text { communicate in English, they felt shy and } \\
\text { not confidence to make presentations. They } \\
\text { showed low self-esteem and poor } \\
\text { confidence. }\end{array}$ \\
\hline \multirow[t]{3}{*}{$\begin{array}{l}\text { Self- } \\
\text { development }\end{array}$} & $\begin{array}{l}\text { Time } \\
\text { management }\end{array}$ & $\begin{array}{l}\text { In piles of homework from other subject and } \\
\text { additional task from the CPBL class, the } \\
\text { students complained that they need to stay } \\
\text { up late to complete both works. Some of } \\
\text { them confessed that their habits in } \\
\text { procrastinating made it worse. }\end{array}$ \\
\hline & $\begin{array}{l}\text { Time } \\
\text { constrain }\end{array}$ & $\begin{array}{l}\text { The time given to the students to complete } \\
\text { the tasks was too short and they needed to } \\
\text { juggle between tasks. }\end{array}$ \\
\hline & Teamwork & $\begin{array}{l}\text { As they have been grouped randomly, some } \\
\text { of the group members did not know each } \\
\text { other well. They claimed that some members } \\
\text { were just free riders, irresponsible and not } \\
\text { giving full commitment while completing } \\
\text { the group tasks. Otherwise, some groups } \\
\text { claimed that they have poor teamwork. }\end{array}$ \\
\hline
\end{tabular}


In the beginning, the students made the effort to participate in the CPBL class which some of the student feelings excited to experience these class. As application of CPBL using highly student centred approach, students being exposed to the new way of learning. They have to develop new skills and way of thinking to cope with the new approach. For instance, rather than received notes from the teachers, the students were asked to make their own notes and peer teach their team members, make an effort to learn something new and decide what to learn and how to learn [2]. However due to the new environment and self-learning approach which require them to find the information themselves, students start to feel the burden and becoming pressured. One of the students wrote:

"In the beginning of the class I feel excited with PBL class. But on the following weeks I become more pressured and exhausted because I need to sleep late at night until 2 or 4 am only to finish the CPBL task and my homework" (Student 01)

The students felt stressed at the early phase of the CPBL class because they needed to juggle between the CPLB tasks and other homework. They also faced certain issues among the group members especially those who were social loafing in the group. A student wrote:

"When I joined CPBL class I have learned many things about PBL. My emotion was so stressed because at that time there were lots of things I need to do such as understand my friends, how to do my responsibility and be patience in everything" (Student 77)

However, in this phase the students realize that the CPBL class was beneficial to them in adding new knowledge for them and had changing their perspective about low carbon issues. For example, these students responded on gaining knowledge and shifted their paradigm on low carbon society issues:

"Also, in term of general knowledge, I have learned about Low Carbon Society and how it is planned and executed in Malaysia and other countries, about Iskandar Malaysia and it main projects, what invention that are invented that aid the environment and effort that other nation implemented to save the environment" (Student 13)

"In future, I want to change our country to become more sustainable like other county even be more develop. My plan and action is to educate the Malaysian children task performance protect the earth. For instance, applied 3R, no plastic or build a non-smoke machine" (Student 06)

From Table 1, it shows the students reflection in phase 1 which provides evidence that despite the traumatic feeling experienced by the students, they acknowledged the benefits of the CPBL class to improve themselves. The new learning approach that requires them to be more independent in seeking information makes students feel reluctant to continue the CPBL class. However, with the motivation and encouragement from the teachers and group members they

could embrace the CPBL activities and looking forwards on the next phase.

\section{B. Student Development in Cycle 2: Discovering New Self-Development and Skills}

The second cycle required the students to identify the problems and collect evidence of the problems. In this cycle, the students need to identify the problems. This cycle involved the students to peer teaching, synthesize information and formulate solution for the identified problem [2]. The students were required to be more proactive as the activities involve collecting data via observation, survey and interview. Meanwhile, the students still experienced the traumatic elements (stress, pressure, time constrain) but it was no longer severe like cycle 1 as they were less mentioned in the reflection. This is because they had learned to adapt to the new self-learning approach from cooperative learning and make an effort to adjust to the learning session and working as a team. From Table 2, students' improvement on cycle 2 can be identified.

In terms of knowledge, the students gain more knowledge about the issues. In this research, all the students from the CPBL class were exposed to the low carbon issues, they became more aware of the environment issues and decided to protect the environment. They started to shift their paradigm towards their role in protecting the environment. A student wrote:

"PBL class was aimed to give awareness to the community about the importance of protecting the environment and reduce the carbon so the earth can become healthier for living" (Student 41)

In cycle 2, the students conducted research which allowed them to meet people, asking their opinions and giving out questionnaire. From this activity, the students gained more confidence to meet strangers, present their research progress and findings to the whole class and make more discussions within their team members. Besides that, they increased their self-esteem by experiencing improvement such as able to communicate more fluently, becoming braver, able to manage their time better and initiate self-learning. A student wrote:

"Through interview we can be brave because we need to talk to another people. It also helps me to be more confident" (Student 36)

One of the methods in presenting their findings is by using Microsoft Power Point. The students learned to use power point to make presentation. They improved their computer literacy and can apply the knowledge for future learning tasks. A student wrote:

"My teacher encouraged us to present our power point confidently" (Student 40) 
Despite the positive improvement gained in this cycle, the students still faced difficulties in time management and team work.

Table- II: The description on the development area during CPBL cycle 2.

\begin{tabular}{|c|c|c|}
\hline $\begin{array}{l}\text { Development } \\
\text { Area }\end{array}$ & Coding & Description \\
\hline \multirow[t]{2}{*}{ Cognitive } & Shift paradigm & $\begin{array}{l}\text { Some students realize the importance of } \\
\text { environment issues while doing the } \\
\text { research on the given topics and making } \\
\text { a benchmarking. They had shifted their } \\
\text { paradigm to protecting the environment. }\end{array}$ \\
\hline & Knowledge & $\begin{array}{l}\text { The issues used in the CPBL class is } \\
\text { about low carbon society which are new } \\
\text { to the students. They realized that they } \\
\text { are able to gain new knowledge from the } \\
\text { class activities and while finding the } \\
\text { information themselves. }\end{array}$ \\
\hline \multirow[t]{3}{*}{ Psychological } & Stressed & $\begin{array}{l}\text { The students become more matured in } \\
\text { handling stress by make more effort and } \\
\text { manage their time to handle both } \\
\text { homework and CPBL tasks. They } \\
\text { realized the importance of time } \\
\text { management. }\end{array}$ \\
\hline & Confidence & $\begin{array}{l}\text { Experiencing CPBL activities had } \\
\text { improved their confidence in } \\
\text { communicate and presenting in front of } \\
\text { others. They had become braver and able } \\
\text { to share their ideas with others. }\end{array}$ \\
\hline & Self-esteem & $\begin{array}{l}\text { Even though students faced difficulties } \\
\text { in the CPBL class, somehow in a } \\
\text { positive way they realize that PBL class } \\
\text { was able to help them to improve } \\
\text { themselves in the future. They are } \\
\text { expecting some positive changes in them } \\
\text { such as become more confident, braver, } \\
\text { improve their English and have better } \\
\text { time management skill. }\end{array}$ \\
\hline \multirow[t]{3}{*}{$\begin{array}{l}\text { Self- } \\
\text { management }\end{array}$} & $\begin{array}{l}\text { Time } \\
\text { management }\end{array}$ & $\begin{array}{l}\text { In piles of homework from other subject } \\
\text { and additional task from the CPBL class, } \\
\text { the students complained that they need to } \\
\text { stay up late to complete both works. } \\
\text { Some of them confessed that their habits } \\
\text { in procrastinating made it worse. }\end{array}$ \\
\hline & $\begin{array}{l}\text { Time } \\
\text { constrain }\end{array}$ & $\begin{array}{l}\text { The time given to the students to } \\
\text { complete the tasks was too short and they } \\
\text { needed to juggle between tasks. }\end{array}$ \\
\hline & Teamwork & $\begin{array}{l}\text { Some members were being free rider, } \\
\text { irresponsible and not giving full } \\
\text { commitment while completing their } \\
\text { group task which lead to some conflict. }\end{array}$ \\
\hline \multirow[t]{3}{*}{ Skills } & $\begin{array}{l}\text { Computer } \\
\text { literacy }\end{array}$ & $\begin{array}{l}\text { The students need to present their } \\
\text { research findings using power point and } \\
\text { they become good at it. }\end{array}$ \\
\hline & Research skill & $\begin{array}{l}\text { In order to find the actual problem, the } \\
\text { students went through the research } \\
\text { procedure from doing collecting data to } \\
\text { analysis the findings from the data. }\end{array}$ \\
\hline & $\begin{array}{l}\text { Communicati } \\
\text { on in English }\end{array}$ & $\begin{array}{l}\text { The students need to deliver their } \\
\text { presentation in English. Thus, there } \\
\text { practiced English and made } \\
\text { improvement. }\end{array}$ \\
\hline
\end{tabular}

\section{Student Development in Cycle 3: Establishing Self Development and Skills}

In the last cycle, the students need to suggest a solution to address the issues found from the research findings in cycle 2 . They need to explain the solution that they propose and receive feedback from the whole class. From this activity the students were able to communicate and justify their decision in both oral and written forms. Each team prepared a written final report from cycle 1 to 3 .
Table III shows the social development and self-development of the students in cycle 3. As the CPBL activities involve self-development, knowledge construction, interaction among team members and the whole class interaction the development became more obvious. This learning approach helps to enhance students' social skill such as team work, communication and showing commitment [10] This means that the systematic cycles in CPBL activities; self-development, knowledge construction and interaction among team members and the whole class interaction have effectively developed social development behaviour amongst the students. The social development shows that the cooperative learning elements in CPBL were able to function as it was intended in the design of CPBL. This learning environment became a platform to enhance students' social skills such as communication, team working and leadership. They wrote:

"I am happy because my teammates have done our best for the team and helping each other's" (Student 56)

"I have gained lots of experience with my teammates by discussing and pull of our effort to complete the task" (Student 59)

Table- III: The description on the development area during CPBL cycle 3.

\begin{tabular}{|c|c|c|}
\hline $\begin{array}{l}\text { Development } \\
\text { Area }\end{array}$ & Coding & Description \\
\hline \multirow[t]{3}{*}{ Behaviour } & Committed & $\begin{array}{l}\text { The students worked together and need } \\
\text { to work together to accomplish the given } \\
\text { tasks }\end{array}$ \\
\hline & Motivated & $\begin{array}{l}\text { Through encouragement and guidance } \\
\text { from teachers, the students became more } \\
\text { motivated to improve themselves. }\end{array}$ \\
\hline & Confident & $\begin{array}{l}\text { From the experience of CPBL activities, } \\
\text { they became braver to convey their idea } \\
\text { effecively. }\end{array}$ \\
\hline \multirow[t]{2}{*}{$\begin{array}{l}\text { Interpersonal } \\
\text { skills }\end{array}$} & $\begin{array}{l}\text { Communication } \\
\text { skills }\end{array}$ & $\begin{array}{l}\text { The students became more accustomed } \\
\text { to using English in their presentations. }\end{array}$ \\
\hline & Teamwork & $\begin{array}{l}\text { The students established teamwork by } \\
\text { completing the tasks together and } \\
\text { sharing opinions. }\end{array}$ \\
\hline \multirow[t]{2}{*}{$\begin{array}{l}\text { Skills } \\
\text { development }\end{array}$} & $\begin{array}{l}\text { Innovation and } \\
\text { creativity }\end{array}$ & $\begin{array}{l}\text { To propose a solution, the students } \\
\text { found innovative and creative ways to } \\
\text { overcome problems they had identify. }\end{array}$ \\
\hline & Problem solving & $\begin{array}{l}\text { The whole process in CPBL assist } \\
\text { student to relate the learning issues to } \\
\text { environment, to identify the actual } \\
\text { problems and finding the best solution to } \\
\text { overcome or reducing the problems. }\end{array}$ \\
\hline
\end{tabular}

The other new added value includes the students developed innovation and creative thinking while identifying solution for the problems. They need to formulate an idea and discussing with the whole team to find one best solution for their team. In this process, the students were going through questions and answers, learn to deliver and convince their ideas to their team members. From the discussion they might come out with new idea or able to improvise the proposed idea. The students were also able to improve their English as they were practising to communicate in English. After using the English language repeatedly, they became more articulate and confidence to speak in English. They wrote:

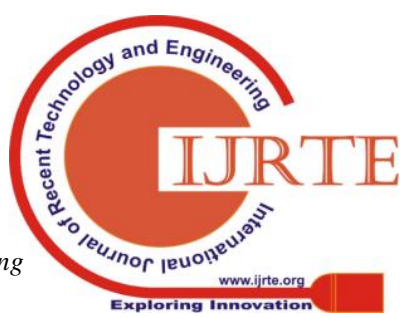


"What I have learned in this PBL class is thinking about an innovative solution for the problem on waste management. We need to use our brain to think about the idea for the solution. The good think in this stage 3 , students can think out of the box to find a good and creative idea" (Student 12)

"Each team member needs to give a solution. Next, the ideas were collected and combined to find the best solution. We always going in front to present out discussion" (Student 78)

"I am happy to finish this programme by saying "it was awesome' because it does help in improving my English" (Student 56)

Besides that, the students engaged more in the CPBL class with encouragement and support from their teachers. When they felt that they could not accomplish the tasks their teachers motivated and supported their efforts, so that they became confident and believed in their abilities. This finding supported that one of the key players in delivering CPBL approach is the role of the teachers. Teachers can make effective intervention and support students in adopting to the new way of learning. The effective teaching and learning approach form CPBL can ensure the need for present and future generation are being understood and fulfilled [10].

"From the PBL activities, I can say that the teacher really supports us and support our ideas. We were able to do the work with our best as the teacher want to see our work have been done perfectly" (Student 50)

From the reflection, the students presented different attitude at the beginning and at the end of the CPBL class. In the early stage (cycle 1) a lot of the reflections show negative attitude but as they came to the end (cycle 3), the reflections show more positive attitude as present in Figure 1.

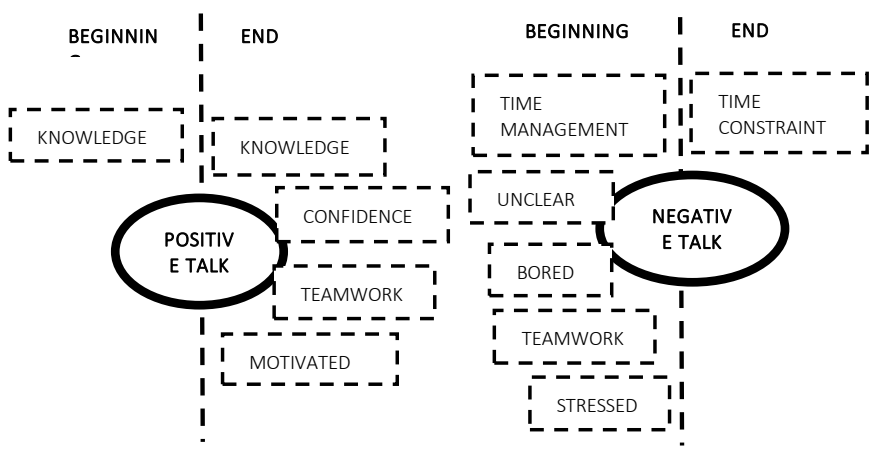

Figure-I: Comparison of positive and negative talks in the reflections by the students between the beginning and end of CPBL class.

\section{CONCLUSION}

CPBL approach is able to impact the students' self-development. The learning process which focuses more on student-centred learning has developed professional skills and other qualities in the students. Through CPBL cycles, the students were exposed to learn knowledge, teamwork, problem solving, and interpersonal skills such as confidence, and communication skills. They also acquired computer literacy, improvement in English, learn time management and some students reported improvement in their studies. As the trauma cycle of CPBL is evidenced, there are some negative reactions at the beginning of the CPBL class because they needed to adapt to the new learning approach. However, after more cycles of CPBL, the students started to adapt to the approach and they became more confidence in accomplishing the tasks with motivation and support from the teachers and their team members.

On the environmental awareness, this CPBL class is a continuation from the Iskandar Malaysia Ecolife Challenge [13] to further improve and strengthen the students' awareness on low carbon society.

\section{ACKNOWLEDGMENT}

The project is supported by the Universiti Teknologi Malaysia's UTMSHINE Grants Vot no. Q.J130000.2431.03G77 and Q.J130000.2453.07G81.

\section{REFERENCES}

1. Adi, F.M., Phang, F.A., and Yusof, K.M. (2012). Student perceptions change in a chemical engineering class using cooperative problem based learning (CPBL). Procedia-Social and Behavioral Sciences, 56, 2012 pp.627-635.

2. Phang, F. A., Yusof, K. M., Abd Aziz, A., Nawi, N.D. and Musa, A.N.. "Cooperative problem-based learning to develop 21st century skills among secondary school students through STEM education." IEEE 2017 7th World Engineering Education Forum (WEEF), 2017. pp. 405-409

3. Husin, Wan Nor Fadzilah Wan, Nurazidawati Mohamad Arsad, Oziah Othman, Lilia Halim, Mohamad Sattar Rasul, Kamisah Osman, and Zanaton Iksan. "Fostering students' 21st century skills through Project Oriented Problem Based Learning (POPBL) in integrated STEM education program." In Asia-Pacific Forum on Science Learning and Teaching, vol. 17, no. 1, pp. 1-18. The Education University of Hong Kong, Department of Science and Environmental Studies, 2016.

4. Mohd-Yusof, Khairiyah, Fatin Aliah Phang, Mohd Johari Kamaruddin, Mimi Haryani Hassim, Haslenda Hashim et al. "Inculcating sustainable development among engineering students, part 1: designing problems and learning environments with impact." Proceedings Engineering Education for Sustainable Development .2013. pp 20-22.

5. Peen, Tan Yin, and Mohammad Yusof Arshad. "Teacher and student questions: A case study in Malaysian secondary school problem-based learning." Asian Social Science 10, no. 4. 2014.174

6. Barrows, H. S., and A. C. Kelson. "Problem-based learning in secondary education and the problem-based learning institute." Springfield, IL: Problem-Based Learning Institute 1, no. 1. 1995. pp 1-5.

7. Hmelo-Silver, Cindy E. "Problem-based learning: What and how do students learn?" Educational psychology review 16, no. 3. 2004. pp 235-266.

8. Mohd-Yusof, Khairiyah, Fatin Aliah Phang, and Syed Ahmad Helmi. "How to develop engineering students' problem solving skills using cooperative problem based learning (CPBL)." In Engineering Leaders World Congress on Engineering Education 2013, vol. 2014, no. 3, p. 30

9. Penfield, Wilder. Mystery of the mind: A critical study of consciousness and the human brain. Princeton University Press, 2015

10. Yusof, K. Mohd, Aziatul Niza Sadikin, Fatin Aliah Phang, and A. Abdul Aziz. "Instilling professional skills and sustainable development through Problem-Based Learning (PBL) among first year engineering students." International Journal of Engineering Education 32, no. 1. 2016. pp 333-347.

11. Yusof, Khairiyah Mohd, Syed Ahmad Helmi Syed Hassan, Mohammad Zamry Jamaludin, and Nor Farida Harun. "Cooperative problem-based learning (CPBL): Framework for integrating cooperative learning and problem-based learning." Procedia-Social and Behavioral Sciences 56. 2012. pp 223-232. 
12. Braun, Virginia, and Victoria Clarke. "Using thematic analysis in psychology." Qualitative research in psychology 3, no. 2 .2006). pp 77-101.

13. Phang, F. A., Wong, W. Y., Ho, C. S., Fujino, J., Aerma Nurazalina Musa, \& Suda, M. (2016). Iskandar Malaysia Ecolife Challenge: Low carbon education for teachers and students. Clean Technologies and Environmental Policy, 18(8), 2525-2532.

\section{AUTHOR PROFILE}

Nor Hidayah Abd Radzaz received the Bachelor in Psychology (Industrial and Organizational Psychology) from Universiti Teknologi Malaysia in 2011 and Ph.D in Management with specialization area on Industrial and Organizational Psychology from Universiti Teknologi Malaysia in 2018. She is currently Research Officer at Uni-Technology Sdn. Bhd. and Research Assistant at Centre for Engineering Education and Low Carbon Asia Research Centre at Universiti Teknologi Malaysia. Her interests are in Psychology education, Cooperative problem based-learning, Multi-level study, Low Carbon, Safety Climate, Safety behaviour and Performance. She works close with Centre for Engineering Education and Low Carbon Asia Research Centre at Universiti Teknologi Malaysia in understanding the impacts of Problem Based Learning among the secondary school's students with the theme of low carbon.

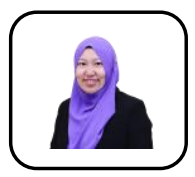

Nina Diana Nawi received the B.Sc. (Hons) in Physics from Universiti Teknologi Malaysia in 2011 and Ph.D in Plasma Physics from Universiti Teknologi Malaysia in 2016. Currently, she is the senior lecturer in Faculty of Social Science and Humanities. Physics education, Cooperative problem based-learning, low carbon, Dense plasma focus, ion beam dynamics, modeling and simulation were her field of interest. The experience with the Centre for Engineering Education and Low Carbon Asia Research Centre at $\overbrace{\text { Universiti Teknologi Malaysia as makes her }}$ anticipate to understand the impacts of Problem Based.

Fatin Aliah Phang received her $\mathrm{PhD}$ at University of Cambridge in Education in 2009. She is now an Assoc. Prof. at the School of Education, Universiti Teknologi Malaysia (UTM). She is also the Research Fellow at the Centre for Engineering Education, UTM. Her research area is in Physics education, focusing on problem-solving, metacognition and qualitative research methodology. She is also working on the fields of engineering education and low-carbon society awareness and education. She is the Co-Chair of Science Education working group of Young Scientists Network (YSN) - Academy of Sciences Malaysia (ASM). 